\title{
The features of metabolism and structural organization of dental system under conditions of experimental insulin resistance
}

\author{
S.P. Guranych'1, M.M. Bagriy ${ }^{2}$, T.V Guranych ${ }^{1}$, N.M. Voronych-Semchenko ${ }^{1}$ \\ ${ }^{1}$ Ivano-Frankivsk National Medical University, Ukraine; \\ ${ }^{2}$ Institute of the Pathology and Cytology, Clinik of Medical School of Brandenburg, Neuruppin, \\ Germany; e-mail: guranichtanja@ukr.net
}

\begin{abstract}
Peculiarities of calcium homeostasis, the activity of energy synthesis enzymes and structural organization of the dental system in rats under conditions of insulin resistance were analyzed. It was found that impaired glucose tolerance is manifested by a decreased mineralizing ability of hard tissues of alveolar processes and teeth, accompanied by a decrease in calcium content in erythrocyte mass and alveolar processes and an increase in acid phosphatase activity in blood serum. In rats with insulin resistance a decrease in the activity of lactate- and succinate dehydrogenase was detected. Degenerative changes were observed in the bone thickness of the dental area of insulin resistant rats, which were accompanied by the development of hypercellularity of the osteogenic layer of periosteum. Reactive changes in the tooth pulp were manifested by a decrease in the area of its loose connective tissue. Hyperplastic changes with the formation of unexpressed acanthotic bands developed in the oral mucosa of experimental animals, the thickness of the basal and granular layers increased against the background of a decrease in the prickle layer of epitheliocytes. In experimental group we observed a decrease in the nuclear cytoplasmic index and an increase in keratin formation in the epithelium. A narrowing of the lumen of capillaries and arterioles of the dental area, hyperplasia of endothelial cells and an increased accumulation of glycoproteins, especially in small arteries, were also detected in experimental group. Thus, altered carbohydrate metabolism leads to the metabolic changes of teeth supporting apparatus and oral mucosa, aggravating the course of insulin resistance with the development of dental system pathology.

Key words: insulin resistance; dental system; metabolic processes; morphology.
\end{abstract}

\section{INTRODUCTION}

Metabolic and energy disorders that occur under conditions of insulin resistance (IR) are the result of violation of metabolic response of target cells to the effects of endogenous or exogenous insulin. It is known that reduced insulin secretion or decreased sensitivity of receptors to its action is accompanied mainly by catabolic manifestations of metabolic processes. The consequence of such changes is an imbalance of all links of metabolism, including mineral homeostasis [1]. Prolonged hyperglycemia leads to the development of so-called diabetic osteopathy: decreased bone density due to reduced absorption of calcium ions in the intestine and their reabsorption in the nephrons tubules, consequently, impaired calcium metabolism, particularly in bones and teeth [2]. It is known that insulin is involved in the regulation of calcium absorption from the lumen of small intestine into the blood plasma by the expression of transcellular and paracellular transporters of macronutrient in enterocytes and, therefore, IR can be the reason of intestinal hypocalcemia [3]. In addition, alterations in carbohydrate metabolism, mainly due to glycation processes, that increase the manifestations of osteoblasts apoptosis with their gradual replacement by adipose tissue, inhibit the differentiation of osteocytes, supress

(C) S.P. Guranych, M.M. Bagriy, T.V Guranych, N.M. Voronych-Semchenko 
the synthesis of type I collagen, osteonectin, osteocalcin. The final manifestation of such changes is a decrease in the number of mature forms of osteoblasts, activation of osteoclasts and impaired mineralization of hard tissues of the organism [4]. However, excessive formation of proinflammatory cytokines and free radicals, as well as imbalance in the synthesis of macroergs, which occur under conditions of impaired glucose tolerance, can aggravate the course of IR and lead to multiorgan disorders, in particular, structural and metabolic changes of periodontal tissues. The changes of oral cavity organs often act as predictors of metabolic disorders of diabetes mellitus, preceding the appearance of its classic clinical symptoms [5].

The functional state of periodontal tissues is negatively affected by changes of the protective, barrier and sensory properties of the oral mucosa (OM), which undergoes significant changes under IR. Glucose-mediated damage of capillary endotheliocytes promotes the hypersecretion of proinflammatory cytokines and accumulation of extracellular matrix proteins. Such disturbances cause hyperfiltration of plasma from the vascular net, hemorrhage appearance, development of hypoxia and metabolic acidosis [6]. Intracellular changes of $\mathrm{OM}$ are associated with the functional properties of mitochondria, which respond by the changes of membrane-binding enzymes activity, which are markers of energy metabolism and the course of hypoxia [7, 8]. In general, the development of IR can disrupt the structural and functional organization of the enzymatic complexes of the mitochondrial respiratory chain, which potentiates the lesion of the dental area.

In the study we aimed to characterize the peculiarities of the metabolism and structural organization of the dental system under conditions of experimental IR.

\section{METHODS}

The study was carried on male rats weighing 150-180 g. Rats were divided into experimental and control groups. The animals of experimental group (IR, $\mathrm{n}=30$ ) received $10 \%$ fructose solution instead of drinking water for eight weeks [9]. Rats of the control group $(n=30)$ were kept on a standard diet, normal temperature and light regime. The animals were sacrificed by decapitation under ketamine anesthesia (Ketamine, OJSC «Farmak», Kyiv, Ukraine, 100 mg/ $\mathrm{kg}$ body weight intraperitoneally) [10]. The development of IR was determined by HOMA-IR index (Homeostasis Model Assessment Insulin Resistane), which was calculated by the content of insulin and glucose in the blood serum, and the level of glycosylated hemoglobin (HbA1c) in whole blood was examined. The insulin level was investigated by using reagent "ELISA RIT" (USA), glucose concentration and the HbAlc content were determined by using kits «Reagent» (Dnipro, Ukraine). The measurements were performed on a plate enzyme-linked immunosorbent assay STAT FAX 2100 (China). The calcium content was examined in erythrocyte mass, alveolar processes and teeth by atomic adsorption spectrophotometry [11]. The activity of alkaline and acidic phosphatases (AP) [12], malate dehydrogenase (MDH), lactate dehydrogenase $(\mathrm{LDH})$ and succinate dehydrogenase (SDH) [7] were also determined in the blood serum.

For general and special histological examinations, the fragments of the OM, bone tissue and teeth were fixed in a $10 \%$ solution of neutral formalin ( $\mathrm{pH} 7.0$ ) for $24 \mathrm{~h}$. The bone pieces and teeth were subjected to acid decalcification for two days. Formation of serial paraffin sections of OM, bone tissue and teeth with a thickness of 4-6 $\mu \mathrm{m}$ was performed on a sledge microtome. Histological sections of examined tissues were stained with hematoxylin and eosin, alcian blue according to Sidman and PAS-staining was performed [13]. The studies were performed on a Leica DME optical microscope (Germany). In order to objectify the quantitative data, the computer morphometry and densitometry of objects in histological specimens were performed using a Nikon Coolpix 4500 digital camera. Subsequently, digital copies of the image were analyzed using the computer program Image Tool 
3.0 for Windows. The morphometric analysis of bones and teeth was performed taking into account the thickness of bone lamellae, the area of intertrabecular connective tissue of bone per one cell, the optical density of the osteogenic matrix of the bone, the area of loose connective tissue of the tooth pulp per cell, the optical density of ground substance of loose connective tissue of the tooth pulp. The morphometric analysis of OM was performed taking into account the epithelial thickness, depth and width of acanthosis, thickness of basal, prickle, granular, keratinized layers of epithelium, perimeter and area of cells of all epithelial layers, perimeter and area of the cells nucleus of all epithelium layers, optical density of the ground substance of the connective tissue.

Experimental procedures were carried out in compliance with the basic provisions of the Rules for the experiments with the using of laboratory animals (1977), the Council of Europe Convention for the Protection of Vertebrate Animals Used in Experiments and Other Scientific Purposes (1986), EEC Directive No. 609 (1986), the Order of the Ministry of Health of Ukraine No. 281 of 01.11 .2000 «About measures to further improve the organizational standards of work with the use of experimental animals» and the Law of Ukraine No. 3447-IV «About the protection of animals from cruelty».

Statistical analysis of digital results of the study was performed using the computer program Excel package Microsoft Office 365 ProPlus. For each of the samples, the distribution of the studied indicator was checked using the Kolmogorov-Smirnov and Liliefors criteria. Considering that the obtained data corresponded to Gauss's law, the results were presented by the interval $\mathrm{M} \pm \mathrm{m}$. Student's t-criterion was used to assess the significance of differences between the groups. The difference in parameters at $\mathrm{P}<0.05$ was considered statistically significant.

\section{RESULTS AND DISCUSSION}

In animals of the experimental group the changes of carbohydrate metabolism markers were observed, which characterize the development of IR (Table 1). Thus, in the blood serum of experimental animals, the glucose and insulin levels we increased by $41.71 \%(\mathrm{P}<0.001)$ and $32.68 \%(\mathrm{P}<0.001)$, respectively, compared to data in rats of the control group. Under such conditions, the increased HOMA-IR index (by $68.06 \%, \mathrm{P}<0.001$ ) in animals of the same group relative to the control group was found. The level of $\mathrm{HbAlc}$ in animals of the experimental group increased by $86.58 \%(\mathrm{P}<0.05)$ compared to baseline values, reflecting altered glucose utilization by target cells on the background of hyperglycemia and hyperinsulinemia.

Under conditions of impaired glucose tolerance, the changes of calcium homeostasis were observed (Table 2). In particular, a decrease of macronutrient content in the erythrocyte mass, alveolar processes and teeth of rats with IR, by $86.67 \%(\mathrm{P}<0.05), 68,00 \%(\mathrm{P}<0.01)$ and $68,65 \%(\mathrm{P}<0.001)$, respectively, was detected relative to similar indicators in animals of the control group. Under such conditions in insulin resistant animals, the activity of serum AP increased by 2.25 times $(\mathrm{P}<0.01)$ relative to baseline. Alcaline phosphatase activity under these experimental conditions had tendency

Table 1. Markers of carbohydrate metabolism in intact and insulin resistant rats $(M \pm m ; n=30)$

\begin{tabular}{l|c|c|c|c|}
\hline \multicolumn{1}{c|}{ Groups of animals } & $\begin{array}{c}\text { Glucose, } \\
\mathrm{mmol} / \mathrm{l}\end{array}$ & Insulin, $\mu \mathrm{U} / \mathrm{l}$ & $\begin{array}{c}\text { Glycosylated } \mathrm{Hb}, \\
\mu \mathrm{mol} \text { of fructose/g } \\
\mathrm{Hb}\end{array}$ & $\begin{array}{c}\text { HOMA-IR } \\
\text { index }\end{array}$ \\
$\begin{array}{l}\text { Control (intact animals) } \\
\begin{array}{l}\text { Experimental (animals } \\
\text { with insulin resistance) }\end{array}\end{array} \quad 5.98 \pm 0.35^{* * *}$ & $17.66 \pm 0.34^{* * *}$ & $6.81 \pm 0.98^{*}$ & $4.42 \pm 0.33^{* * *}$ \\
\hline
\end{tabular}

Note: Here and in the following tables: $* \mathrm{P}<0.05 ; * * * \mathrm{P}<0.001$ a reliable difference between control indicators 
Table 2. Calcium content in erythrocyte mass, alveolar processes, teeth and serum phosphatases activity of intact and insulin resistant rats $(M \pm m ; n=30)$

\begin{tabular}{|c|c|c|c|c|c|}
\hline \multirow[t]{2}{*}{ Groups of animals } & \multicolumn{3}{|c|}{ Calcium, mg $/ \mathrm{kg}$} & \multirow{2}{*}{$\begin{array}{c}\text { Alkaline } \\
\text { phosphatase, } \\
\text { mccat } / 1\end{array}$} & \multirow{2}{*}{$\begin{array}{c}\text { Acid } \\
\text { phosphatas } \\
\text { units/l }\end{array}$} \\
\hline & $\begin{array}{c}\text { Erythrocyte } \\
\text { mass }\end{array}$ & $\begin{array}{l}\text { Alveolar } \\
\text { processes }\end{array}$ & Teeth & & \\
\hline
\end{tabular}

Control

(intact animals)

$0.75 \pm 0.20 \quad 66.03 \pm 9.37$

$61.31 \pm 4.01$

$4537.47 \pm 596.10$

$2.67 \pm 0.21$

Experimental

(animals with insulin

resistance)

$0.10 \pm 0.01 * \quad 21.13 \pm 1.54 * *$

$19.22 \pm 0.87 * * * \quad 4207.19 \pm 1798.566 .01 \pm 0.76 * *$

Note: Here and in the following Tables: $* * \mathrm{P}<0.01$ a reliable difference between control indicators

to decrease. The specified changes of serum phosphatases reflect a violation of osteosynthetic processes, activation of osteoresorption. When accompanied by a reduced calcium content in the hard tissues of bones and teeth, these changes can cause dysfunction of dental-alveolar complex under conditions of IR [2]. However, hyperglycemia leads to glycation of the organic matrix of the bone, which further exacerbates the manifestations of osteodestruction and osteopenia.

Under the conditions of IR in experimental animals, the changes of parameters in the energy synthesis system were observed, which had a multidirectional nature (Table 3 ). In particular, in the blood serum of rats of the experimental group, the activity of MDH increased by $58.47 \%$ $(\mathrm{P}<0.05)$ relative to control. At the same time, the activity of LDH and SDH under these experimental conditions decreased by $97.75 \%$ $(\mathrm{P}<0.01)$ and $67.62 \%(\mathrm{P}<0.05)$, respectively, compared to the data in intact animals. It is known that under conditions of hyperglycemia, the activity of electron transport system is disrupted as a result of the macroerg donors dificiency. Thus, SDH is an enzyme of the inner membrane of mitochondria, and largely determines the rate of oxygen consumption and ATP formation [14], and LDH catalyzes the initial stages of energy production [15]. Therefore, the predominant decrease in the activity of the studied markers of energy balance can be regarded as a sign of insufficient tissue oxygen supply, dysfunction of the energy biotransformation system, in particular, in periodontal structures.

As a result of morphological examination it was found that bone plates of the outer surface of the bone of the alveolar cavity of animals with IR are located compactly and form the structures of osteons type in some places. In their center, the thin-walled vessels filled with erythrocytes, lined with endothelial cells with elongated homogeneous nuclei are visualized. In contrast to intact animals, in a part of the vessels of the osteon canal of experimental group of rats, a small number the macrophages, lymphocytes are observed along with erythrocytes. The bone matrix shows PAS positivity due to the presence of glycoproteins. The content of glycosaminoglycans, which is detected by staining with alcian blue, is close to the control group (Fig. 1; Table 4).

Table 3. Activity of malate dehydrogenase (MDH), lactate dehydrogenase (LDH) and succinate dehydrogenase (SDH) in the blood serum of intact and insulin resistant rats $(M \pm \mathbf{m} ; \mathbf{n}=\mathbf{3 0})$

\begin{tabular}{l|c|c|c|}
\hline \multicolumn{1}{|c|}{ Groups of animals } & $\begin{array}{c}\mathrm{MDH}, \mu \mathrm{mol} / \\
(\mathrm{min} \cdot \mathrm{mg})\end{array}$ & LDH, mkkat/1 & $\mathrm{SDH}, \mathrm{nmol} / \mathrm{mg} \cdot \mathrm{min}$ \\
\hline $\begin{array}{l}\text { Control (intact animals) } \\
\begin{array}{l}\text { Experimental (animals with } \\
\text { insulin resistance) }\end{array}\end{array}$ & $1.18 \pm 0.15$ & $47.13 \pm 13.54$ & $38.57 \pm 9.98$ \\
\hline
\end{tabular}


Table 4. Morphological characteristics of bone tissue of alveoli cavities and teeth pulp of intact and insulin resistant rats $(\mathbf{M} \pm \mathbf{m} ; \mathbf{n}=\mathbf{3 0})$

\begin{tabular}{|c|c|c|c|c|c|}
\hline $\begin{array}{l}\text { Groups of } \\
\text { animals }\end{array}$ & $\begin{array}{l}\text { Optical density } \\
\text { of osteogenic } \\
\text { matrix, units }\end{array}$ & $\begin{array}{c}\text { Thickness of } \\
\text { bone trabecu- } \\
\text { lae, mkm }\end{array}$ & $\begin{array}{l}\text { Area of intertra- } \\
\text { becular connec- } \\
\text { tive tissue } / 1 \text { cell, } \\
\qquad \mathrm{m}^{2} / 1 \text { cell }\end{array}$ & $\begin{array}{l}\text { Area of loose } \\
\text { connective } \\
\text { tissue of the } \\
\text { pulp } / 1 \text { cell, } \\
\mu \mathrm{m}^{2} / 1 \text { cell }\end{array}$ & $\begin{array}{l}\text { Optical density } \\
\text { of the ground } \\
\text { substance of } \\
\text { the pulp, units }\end{array}$ \\
\hline $\begin{array}{l}\text { Control (intact } \\
\text { animals) }\end{array}$ & $165.58 \pm 3.12$ & $63.89 \pm 1.30$ & $283.19 \pm 11.43$ & $420.00 \pm 6.29$ & $170.88 \pm 2.53$ \\
\hline $\begin{array}{l}\text { Experimental } \\
\quad \text { (animals } \\
\text { with insulin } \\
\text { resistance) }\end{array}$ & $155.15 \pm 4.24$ & $54.92 \pm 2.89^{*}$ & $176.43 \pm 15.29 * * *$ & $395.00 \pm 7.11 *$ & $170.69 \pm 4.33$ \\
\hline
\end{tabular}

The osteocytes with small homogeneous nuclei are located in the bone matrix. Focally, the nuclei of osteocytes are shrunken, have irregular and fuzzy contours, somewhere the nuclei are visualized in the form of shadows, preserving only the veiled contours of the karyolema (Fig. $2)$. In these areas in the osteogenic layer of periosteum the osteogenic hypercellularity is observed, which may be a reaction on degenerative changes in bone thickness under conditions of IR.

Plates in depth form trabeculae, the average thickness of which is less than the control data by $14.04 \%, \mathrm{P}<0.05$ (Table 4 ). The gluing lines

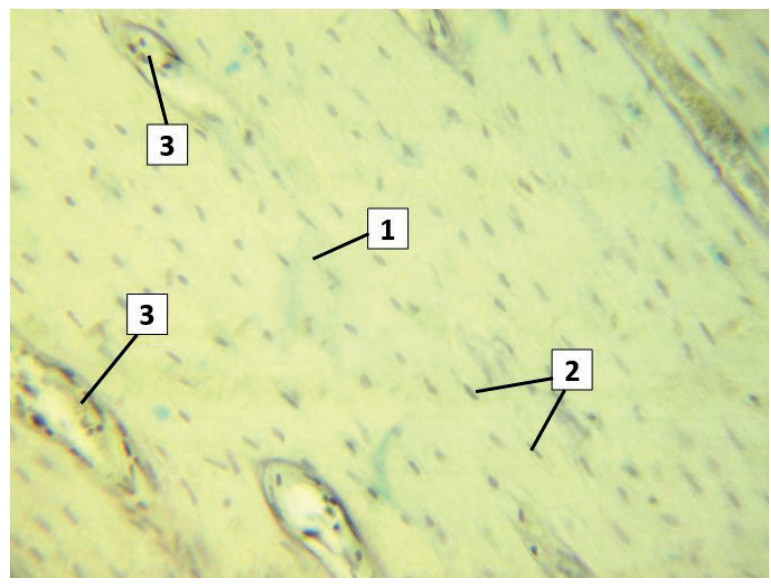

Fig. 1. Bone tissue of the outer plate of the alveolar cavity under conditions of insulin resistance $(1-$ glycosaminoglycans in the osteogenic matrix, 2 - osteocytes, 3 - osteon vessels filled with erythrocytes with single leukocytes). Staining: alcian blue by Steedman, $\times 400$ of plates are basophilic, in some areas clear and thin, in others - blurred. The osteocytes with ovoid and irregular ovoid shape nuclei with homogeneous chromatin are visualized in the thickness of bone trabeculae. The area of enlightenment of the cytoplasm is traced around the nuclei. On the sides of bone trabeculae in a small number the osteoblasts are observed, which are characterized by bigger, compared with osteocytes, the size of the nuclei, with fine chromatin, with a moderate amount of eosinophilic cytoplasm. The osteoblasts are in contact with cells and fibers of the peri- and endosteum. In some areas of the intertrabecular spaces the

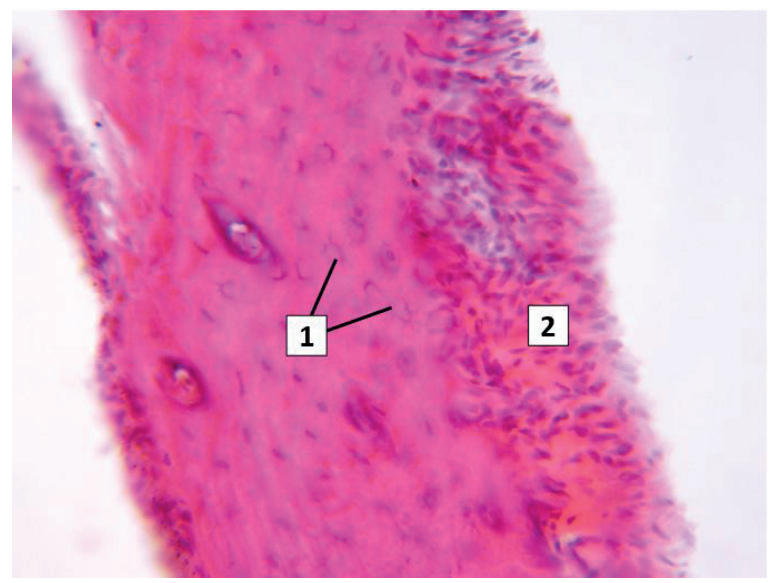

Fig. 2. The outer part of the bone of the alveolar cavity with periosteum under conditions of insulin resistance $(1-$ degenerative changes of osteocytes, 2 - osteogenic layer of periosteum with hypercellularity). Staining: hematoxylin and eosin, $\times 400$ 
hematopoietic, and in others - connective tissue is present.

In the connective tissue that fills the intertrabecular spaces, fibroblasts, fibrocytes, macrophages are differentiated. The fibroblasts are with ovoid, ovoid-rounded shape, fine chromatin, visualization of nucleoli. The nuclei of fibrocytes are more elongated and more homogeneous. The connective tissue fibers of the intertrabecular spaces are loosely arranged. Thin-walled capillaries of various calibers, lined with endothelial cells are visualized in the thickness of the connective tissue. The nuclei of endothelial cells are elongated along the wall, homogeneous. In the lumen of the capillaries there is a small number of erythrocytes, in some capillaries the lumen is free.

There is a periodontal ligament between the bone part of the alveolar cavity and the outer surface of the tooth. It is represented mainly by connective tissue fibers, which are more compactly arranged in comparison with the fibers of the intertrabecular connective tissue. The periodontal fibers have a directional character from the bone tissue to the tooth surface, closely adjoin to the last one. Between the connective tissue fibers in the periodontal ligament there are fibroblasts and fibrocytes and a small number of thin-walled capillaries.

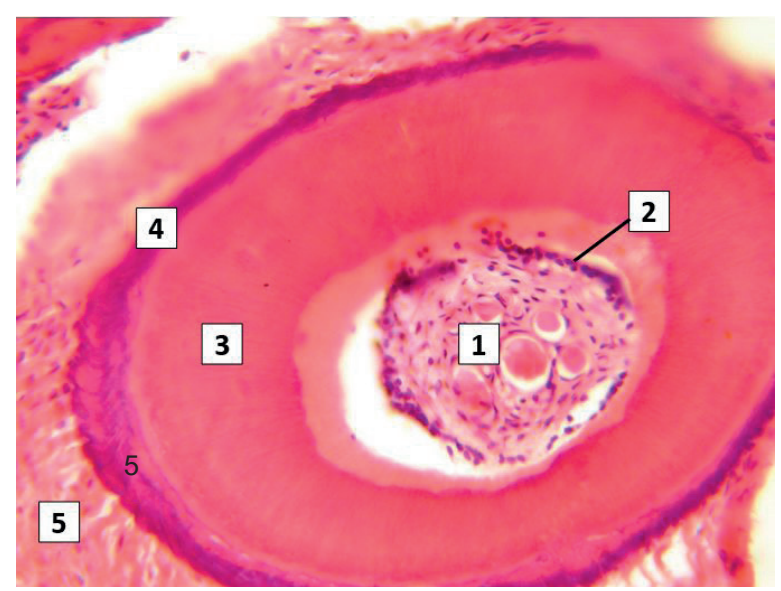

Fig. 3. The root part of the tooth under conditions of insulin resistance $(1-$ pulp with full-blooded vessels and a small number of cells, 2 - odontoblasts, 3 -dentin, 4 - cement, 5 -periodontium). Staining: hematoxylin and eosin, $\times 400$
The root surface of the tooth is covered with cement in the form of a basophilic non-nuclear zone. The main part of the tooth is dentin with numerous radial direction dentinal tubules. There is a pulp in the root canal and pulp cavity. On the border with dentin, the odontoblasts are located, which have round nuclei, fine chromatin, one centrally located nucleolus. The main part of the pulp is connective tissue with connective tissue fibers, fibroblasts, fibrocytes, single macrophages and thin-walled vessels of capillary type, which are filled with erythrocytes (Fig. 3). The reactive changes in the pulp reflect a decrease of the area of loose connective tissue of the pulp per 1 cell (Table 4). The optical density of the ground substance of the pulp, which is stained with alcian blue is not reliably different from the control.

The epithelium of OM has an uneven thickness due to hyperplastic changes with the formation of unexpressed acanthotic cords with a depth of $23.67 \pm 1.95 \mu \mathrm{m}$ and a width of $47.91 \pm 4.65$ $\mu \mathrm{m}$ (Fig. 4). Acanthosis is caused by epithelial basal hypercellularity, in this regard, the cells of the basal layer are arranged in five or six rows.

The thickness of the basal layer of OM of animals with IR exceeds the corresponding parameter in animals of the control group by

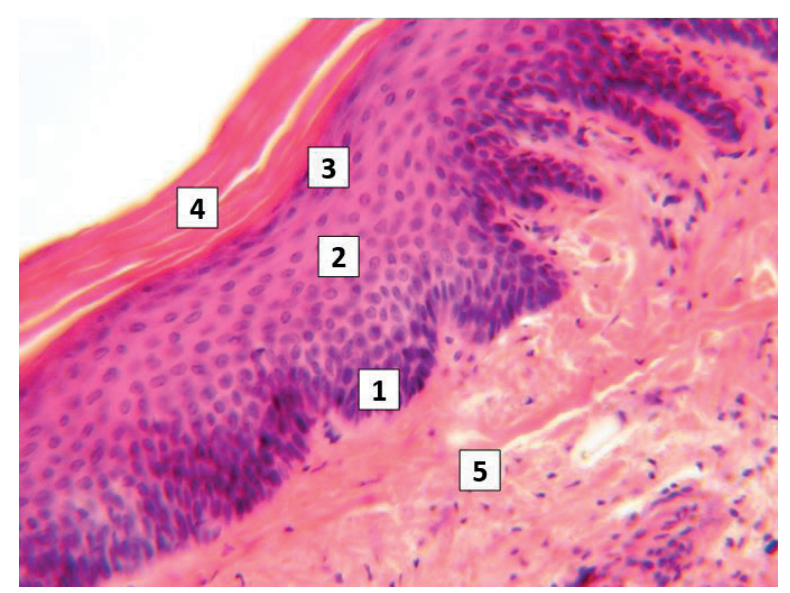

Fig. 4. The epithelium of the mucous membrane of insulin resistant rat (1 - basal layer of epithelium with unexpressed acanthosis, 2 - prickle layer of epitheliocytes, 3 - granular layer of epitheliocytes, 4 - keratinized layer, 5 - subepithelial connective tissue). Staining: hematoxylin and eosin, $\times 400$ 
$53.35 \%(\mathrm{P}<0.05$; Table 5$)$. The area of epithelial cells nuclei of the basal layer of the epithelium exceeds the respective parameter of the control group by $45.06 \%(\mathrm{P}<0.05$; Table 6$)$. In basal epitheliocytes there is a small portion of cytoplasm and an increase in the size of the nuclei of basal epithelial cells, which led to an increase in the nuclear cytoplasmic index by $74.29 \%$ $(\mathrm{P}<0.05)$ comparing to control data. The cytoplasm of cells is eosinophilic-basophilic, veiled. The boundaries of the cells are blurred, due to the rather compact arrangement of epitheliocytes.

The cells of the prickle layer are arranged mainly in five rows. The thickness of this layer of epithelium by $25.97 \%(\mathrm{P}<0.05)$ less than in intact animals (Table 5). Cell nuclei have mostly rounded or irregularly rounded shape, the area of which by $20.74 \%(\mathrm{P}<0.05)$ less than the control data (Table 6). The karyolema of prickle epitheliocytes is clear. In the karyoplasm there is mostly one rounded centrally located nucleolus, fine chromatin. The cytoplasm of cells is eosinophilic, occupies a much larger area, which is accompanied by a decrease in the nuclear-cytoplasmic ratio relative to the cells of the basal layer.

The cells of the granular layer are of slightly flattened shape, elongated along the epithelium and arranged in about three-four rows. The thickness of the granular layer exceeds the con- trol data by $41.00 \%(\mathrm{P}<0.05)$. In the cytoplasm of cells there are multiple small basophilic granules, which are diffusely and evenly distributed throughout the cell. The nuclei of granular epitheliocytes are centrally located, round-ovoid in shape, their perimeter and area are smaller than in intact animals by $20.40 \%(\mathrm{P}<0.05)$ and by $37.00 \%(\mathrm{P}<0.05)$, respectively (Table 6$)$. The nuclei of granular epitheliocytes have fine chromatin, one nucleolus. In a part of the nuclei of cells thickening of the karyolema, irregular contours of the nuclei are marked. An increase in the thickness of the granular layer with a simultaneous decrease in the nuclear-cytoplasmic index characterizes the increased formation of keratin in the epithelium. The non-nuclear keratin zone in the form of an eosinophilic strip with an average thickness of $42.32 \pm 3.61 \mu \mathrm{m}$ is superficially located, which does not differ from the control data $(41.83 \pm 2.15 \mu \mathrm{m})$.

The subepithelial basement membrane after hematoxylin and eosin staining is traced indistinctly, due to fusion with connective tissue fibers. Its clearer visualization is noted in zones of less expressed acanthosis. After PAS-staining it is possible to find the course of a membrane more accurately (Fig. 5).

In subepithelial connective tissue, there is an uneven distribution of macrophages (the majority is localized subepithelially) and lym-

Table 5. Morphological characteristics of the oral mucosa of intact and insulin resistant rats $(\mathbf{M} \pm \mathbf{m} ; \mathbf{n}=\mathbf{3 0})$

\begin{tabular}{|c|c|c|c|c|c|c|c|}
\hline & $\begin{array}{c}\text { Thickness } \\
\text { of the } \\
\text { of animals } \\
\text { epithelium, } \\
\mu \mathrm{m}\end{array}$ & $\begin{array}{c}\text { Thickness } \\
\text { of the basal } \\
\text { layer, } \mu \mathrm{m}\end{array}$ & $\begin{array}{c}\text { Thickness of } \\
\text { the prickle } \\
\text { layer, } \mu \mathrm{m}\end{array}$ & $\begin{array}{c}\text { Thickness of } \\
\text { the granular } \\
\text { layer, } \mu \mathrm{m}\end{array}$ & $\begin{array}{c}\text { Thick- } \\
\text { ness of the } \\
\text { keratinized } \\
\text { layer, } \mu \mathrm{m}\end{array}$ & $\begin{array}{c}\text { Optical con- } \\
\text { tent of glycos- } \\
\text { aminoglycans } \\
\text { in connective } \\
\text { tissue, units }\end{array}$ & $\begin{array}{c}\text { Optical con- } \\
\text { saminoglycal- } \\
\text { perivascularly, } \\
\text { units }\end{array}$ \\
\hline
\end{tabular}

Control

(intact

animals) $\quad 233.75 \pm 10.3542 .64 \pm 2.4693 .77 \pm 6.5419 .88 \pm 2.4541 .83 \pm 2.15169 .56 \pm 3.78167 .33 \pm 2.34$ Experimen-

tal (ani-

mals with

insulin

resistance) $238.00 \pm 13.8965 .39 \pm 6.88 * 69.42 \pm 2.80 * * 28.03 \pm 2.32 * 42.32 \pm 3.00166 .45 \pm 2.81166 .00 \pm 6.08$ 
Table 6. Morphometric parameters of oral mucosal epitheliocytes of intact and insulin resistant $\mathbf{r a t s}(\mathrm{M} \pm \mathbf{m} ; \mathbf{n}=\mathbf{3 0})$

\begin{tabular}{|c|c|c|c|c|c|}
\hline $\begin{array}{c}\text { Groups } \\
\text { of animals }\end{array}$ & $\begin{array}{l}\text { Perimeter of } \\
\text { the cell nucle- } \\
\text { us, } \mu \mathrm{m}\end{array}$ & $\begin{array}{c}\text { Area of the cell } \\
\text { nucleus, } \\
\mu \mathrm{m}^{2}\end{array}$ & $\begin{array}{c}\text { Perimeter } \\
\text { of the cell, } \mu \mathrm{m}\end{array}$ & Cell area, $\mu \mathrm{m}^{2}$ & $\begin{array}{l}\text { Nuclear cyto- } \\
\text { plasmic index }\end{array}$ \\
\hline \multicolumn{6}{|c|}{ Basal layer of epithelium } \\
\hline $\begin{array}{l}\text { Control (intact } \\
\text { animals) }\end{array}$ & $28.99 \pm 1.52$ & $47.45 \pm 6.95$ & $48.52 \pm 1.89$ & $137.38 \pm 10.46$ & $0.35 \pm 0.10$ \\
\hline $\begin{array}{l}\text { Experimental } \\
\text { (animals with } \\
\text { insulin resistance) }\end{array}$ & $34.00 \pm 1.50^{*}$ & $68.83 \pm 3.18^{*}$ & $53.29 \pm 5.78$ & $181.24 \pm 17.27^{*}$ & $0.61 \pm 0.05^{*}$ \\
\hline \multicolumn{6}{|c|}{ Prickle layer of epithelium } \\
\hline $\begin{array}{l}\text { Control (intact } \\
\text { animals) }\end{array}$ & $36.22 \pm 0.46$ & $82.78 \pm 3.65$ & $78.17 \pm 2.65$ & $393.95 \pm 26.87$ & $0.27 \pm 0.13$ \\
\hline $\begin{array}{l}\text { Experimental } \\
\text { (animals with } \\
\text { insulin resistance) }\end{array}$ & $32.68 \pm 0.48^{* * *}$ & $65.61 \pm 3.41^{* *}$ & $73.78 \pm 2.15$ & $349.53 \pm 6.57$ & $0.23 \pm 0.16$ \\
\hline \multicolumn{6}{|c|}{ Granular layer of epithelium } \\
\hline $\begin{array}{l}\text { Control (intact } \\
\text { animals) }\end{array}$ & $34.17 \pm 1.85$ & $63.89 \pm 4.86$ & $81.41 \pm 2.21$ & $263.70 \pm 17.44$ & $0.34 \pm 0.10$ \\
\hline $\begin{array}{l}\text { Experimental } \\
\text { (animals with } \\
\text { insulin resistance) }\end{array}$ & $27.13 \pm 2.15^{*}$ & $40.25 \pm 1.05^{* *}$ & $91.29 \pm 5.16$ & $209.54 \pm 15.36^{*}$ & $0.24 \pm 0.07$ \\
\hline
\end{tabular}

phocytes. The connective tissue is represented mainly by connective tissue fibers, which are arranged compactly, but without a clear order. In capillaries and arterioles of OM, the narrow-

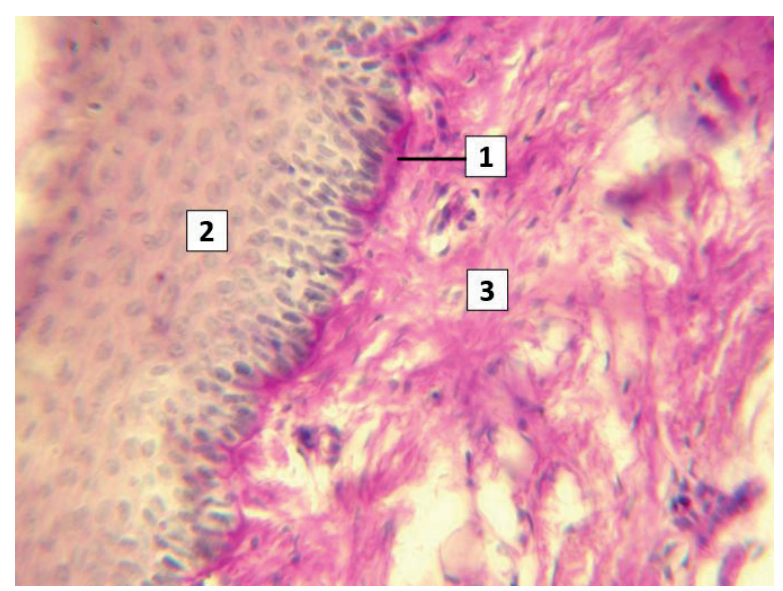

Fig. 5. Mucous membrane under conditions of insulin resistant rats (1 - PAS-positive basement membrane, 2 - epithelium, 3 - subepithelial connective tissue with PAS-positive glycoproteins). Staining: PAS, $\times 400$ ing of their lumen is noted that can be a consequence of plasma impregnation with loosening of vessels wall, in some vessels hyperplasia of endothelial cells is observed (Fig. 6). In this

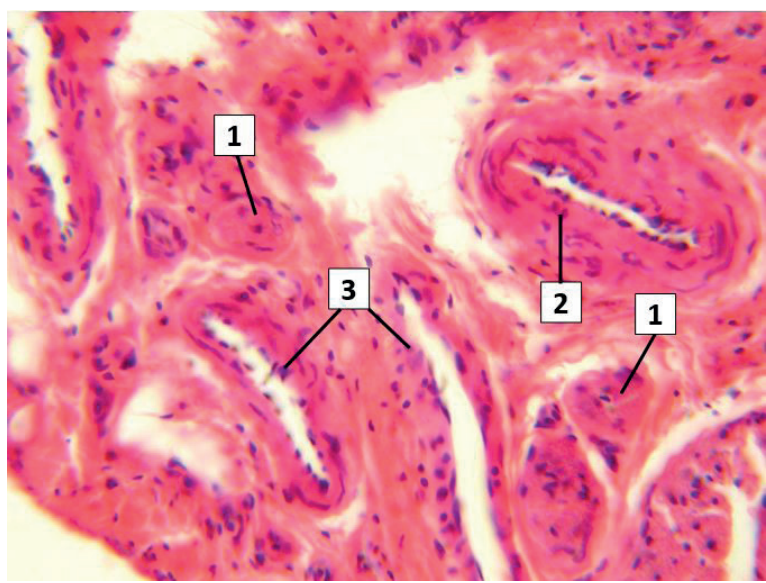

Fig. 6. Vessels of subepithelial connective tissue of the mucous membrane of insulin resistant rat $(1-$ plasma impregnation of the arterioles wall, 2 - artery of muscular type, 3 - veins). Staining: hematoxylin and eosin, $\times 400$ 
case, endotheliocytes with irregularly rounded nuclei, with predominantly homogeneous chromatin penetrate into the lumen of blood vessels. The areas of accumulation of PAS-positive material are noticed in the wall of some arterioles, which reflects the processes of glycosylation of proteins. The lumen of the vessels is mostly free, somewhere with several leukocytes.

The lumen of small arteries is mostly round, free, or with single erythrocytes. Its enhancement in comparison with capillaries and arterioles is noted, however, to a lesser extent, than in small veins. PAS-positive tortuous inner elastic membrane with places of uneven width and depth folds is clearly observed in insulin resistant animals. In areas of increased tortuosity, an aggravation of glycoproteins accumulation is detected. Small arteries with segmentally increased accumulation of PAS-positive material in the wall outside the inner elastic membrane are detected (Fig. 7), which may be a consequence of the negative impact of IR on the structure of vessels.

The muscular membrane of the arteries is represented by several rows of circularly oriented smooth myocytes with ovoid nuclei, which are elongated along the perimeter of the vessel. Smooth myocytes are compactly ar-

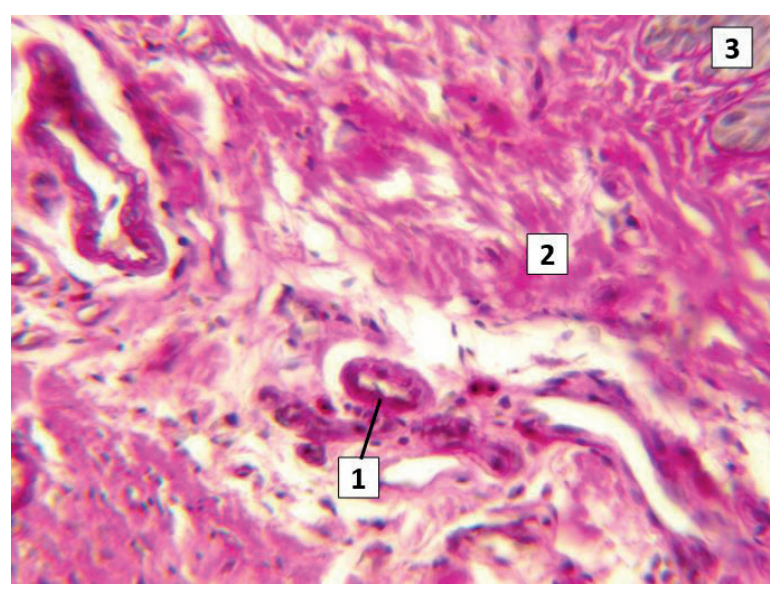

Fig. 7. Vessels of subepithelial connective tissue of the mucous membrane of insulin resistant rat $(1-$ uneven accumulation of glycoproteins in the artery wall, 2 - connective tissue glycoproteins, 3 - acanthosis of the integumentary epithelium of the mucous membrane). Staining: PAS, $\times 400$ ranged. Outwards of the muscular membrane is a thin layer of connective tissue fibers of the adventitia.

Perivascularly, a slight accumulation of glycosaminoglycans is detected, which may lead to a decrease of the optical density of subepithelial connective tissue (Fig. 8). In small veins, the lumen is mostly free or with a small number of erythrocytes. From the inside, the lumen is lined with endothelial cells with ovoid elongated nuclei, outwards - smooth myocytes of the muscular membrane and adventitia.

Keeping rats on a high-fructose diet causes the development of IR, which is confirmed by the changes of carbohydrate metabolism markers (increased HOMA-IR index and HbAlc of blood). Impaired glucose tolerance is accompanied by metabolic disorders and structural rearrangement of the dental system in experimental animals. In particular, the glucose-mediated damage of periodontal structures is manifested by a decrease of the mineralizing ability of hard tissues of bones and teeth, as a consequence of imbalance in calcium homeostasis. The activation of osteoresorptive processes under IR conditions is shown by a decrease of calcium content in all studied tissues against the background of increasing the activity of AP in blood serum.

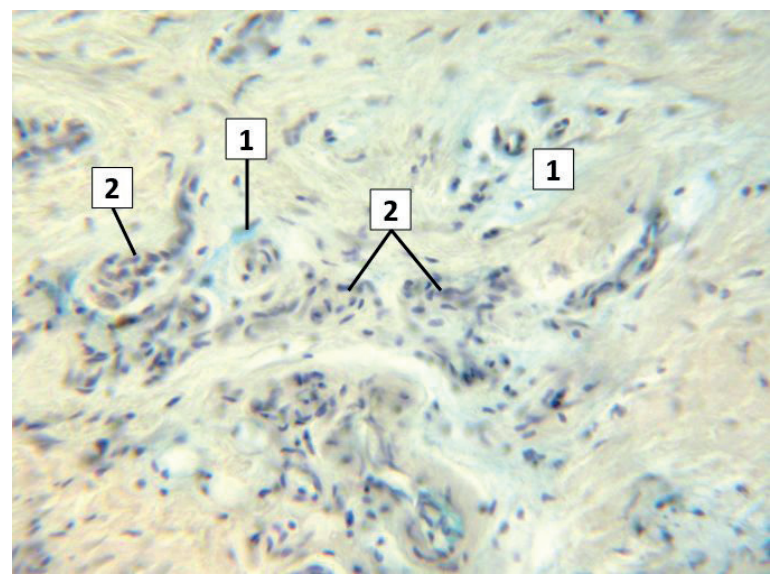

Fig. 8. Glycosaminoglycans in the subepithelial connective tissue of insulin resistant rat (1 - visualization of glycosaminoglycans in the perivascular connective tissue, 2 - small vessels with a narrowed lumen and signs of endotheliosis). Staining: alcian blue by Steedman, $\times 400$ 
However, a significant decrease of LDH and SDH activity in the blood of experimental rats can be regarded as a sign of hypoxia and deficiency of energy biosubstrates, that potentiate the manifestations of osteopathy, lesions of the teeth supporting apparatus and OM. The degenerative changes are formed in the thickness of dental bones of insulin resistant rats, which are accompanied by the development of hypercellularity of the osteogenic layer of periosteum. Reactive changes in the tooth pulp reflect a decrease in the area of its loose connective tissue. In OM of insulin resistant animals, the hyperplastic changes are developed with the formation of unexpressed acanthotic cords, which are caused by epithelial basal hypercellularity. In experimental animals, the thickness of the basal and granular layers was increased against the background of a decrease of the prickle layer of epitheliocytes of OM. A decrease in the nuclear-cytoplasmic index, an increased keratin formation in the epithelium were noticed. In vessels of different caliber of the dental area the following changes are developed: narrowing of the lumen of capillaries and arterioles, hyperplasia of endothelial cells, increased accumulation of glycoproteins, especially in small arteries, that disturb nutrition of tissues. Therefore, it is advisable to determine the calcium content, activity of phosphatases and dehydrogenases of blood serum as one of the early markers of periodontal tissue damage in case of IR or diabetes mellitus development.

\section{CONCLUSIONS}

1. The development of IR is accompanied by a reduction of mineralization ability of hard tissues of the alveolar processes and teeth.

2. The impaired glucose tolerance causes the reactive changes of the teeth pulp, as a consequence of hemomicrocirculatory bed damage.

3. Keeping of rats on a high-fructose diet leads to glucose-mediated metabolic and trophic changes of OM with the predominant development of hyperplastic changes.

The authors of this study confirm that the research and publication of the results were not associated with any conflicts regarding commercial or financial relations, relations with organizations and/or individuals who may have been related to the study, and interrelations of co-authors of the article.

\section{С.П. Гуранич ${ }^{1}$, М.М. Багрій${ }^{2}$, Т.В. Гуранич ${ }^{1}$, Н.М. Воронич-Семченко ${ }^{1}$ \\ ОСОБЛИВОСТІ МЕТАБОЛІЗМУ ТА СТРУКТУРНОЇ ОРГАНІЗАЦІЇ ЗУБОЩЕ- ЛЕПНОЇ СИСТЕМИ ЗА УМОВ ІНСУЛІНО- РЕЗИСТЕНТНОСТІ В ЕКСПЕРИМЕНТІ}

\footnotetext{
${ }^{1}$ Івано-Франківський національний медичний університет, Україна;

${ }^{2}$ Інститут патології та цитології медичної клініки та медичного інституту Федеральної Землі Бранденбург, Німеччина; e-mail:guranichtanja@ukr.net
}

Проаналізовано особливості кальцієвого гомеостазу, активність ферментів енергосинтезу та структурну організацію зубощелепної системи у щурів за умов інсулінорезистентності (перебування на високофруктозній дієті впродовж 8 тиж). Встановлено, що порушення толерантності до глюкози проявляється зниженням мінералізуючої здатності твердих тканин альвеолярних відростків і зубів, що підтверджується зменшенням вмісту кальцію в еритроцитарній масі, альвеолярних відростках, зубах дослідних тварин на 68,00-86,67\% на тлі зростання активності кислої фосфатази сироватки крові у 2,25 раза щодо контролю (інтактні тварини). Аналіз активності дегідрогеназ сироватки крові щурів iз інсулінорезистентністю виявив суттєве зниження активності лактат- (на 97,75\%) і сукцинатдегідрогенази (на 67,62\%), що може характеризувати дефіцит утворення макроергів у результаті гіпоксії тканин. У товщі кісток зубощелепної ділянки інсулінорезистентних щурів спостерігали дегенеративні зміни, що супроводжувалися розвитком гіперклітинності остеогенного шару окістя. Реактивні зміни пульпи зуба проявлялися зменшенням площі її пухкої сполучної тканини. У слизовій оболонці порожнини рота дослідних тварин розвивалися гіперпластичні зміни 3 формуванням невиражених акантотичних тяжів, збільшувалася товщина базального і зернистого шарів на тлі зменшення шипуватого шару епітеліоцитів, зменшувався ядерно-цитоплазматичний індекс, спостерігалося посилення утворення кератину в епітелії. У судинах різного калібру зубощелепної ділянки спостерігалося звуження просвіту капілярів та 
артеріол, гіперплазія ендотеліальних клітин, збільшення накопичення глікопротеїнів, особливо у дрібних артеріях, що змінювало трофіку тканин. Таким чином, порушення вуглеводного обміну призводить до метаболічних змін опорно-утримуючого апарату зубів і слизової оболонки порожнини рота, що ускладнює перебіг інсулінорезистентності розвитком патології зубощелепної системи.

Ключові слова: інсулінорезистентність; зубощелепна система; метаболічні процеси; морфологія.

\section{С.П. Гуранич, Н.Н. Багрий, Т.В. Гуранич, Н.Н. Воронич-Семченко

Проанализированы особенности кальциевого гомеостаза, активность ферментов энергосинтеза и структурная организация зубочелюстной системы у крыс в условиях инсулинорезистентности (пребывание на высокофруктозной диете в течение 8 нед). Установлено, что нарушение толерантности к глюкозе проявляется снижением минерализующей способности твердых тканей альвеолярных отростков и зубов, что подтверждается уменьшением содержания кальция в эритроцитарной массе, альвеолярных отростках, зубах опытных животных на 68,00-86,67\% на фоне увеличения активности кислой фосфатазы сыворотки крови в 2,25 раза по сравнению с контролем (интактные животные). Анализ активности дегидрогеназ сыворотки крови крыс с инсулинорезистентностью выявил существенное снижение активности лактат- (на 97,75\%) и сукцинатдегидрогеназы (на $67,62 \%$ ), что может характеризовать дефицит образования макроэргов вследствие гипоксии тканей. В толще костей зубочелюстной области наблюдали дегенеративные изменения, сопровождающиеся развитием гиперклеточности остеогенного слоя надкостницы. Реактивные изменения пульпы зуба проявлялись уменьшением площади ее рыхлой соединительной ткани. В слизистой оболочке полости рта у них развивались гиперпластические изменения с формированием невыраженных акантотичных тяжей, увеличивалась толщина базального и зернистого слоев на фоне уменьшения шиповатого слоя эпителиоцитов, уменьшался ядерноцитоплазматический индекс, наблюдалось усиление образования кератина в эпителии. В сосудах разного калибра зубочелюстной области наблюдали сужение просвета капилляров и артериол, гиперплазию эндотелиальных клеток, увеличение накопления гликопротеинов, особенно в мелких артериях, что приводило к изменению трофики тканей. Таким образом, нарушение углеводного обмена провоцировало метаболические изменения опорно-удерживающего аппарата зубов и слизистой оболочки полости рта, а это усложняло течение инсулинорезистентности развитием патологии зубочелюстной системы.

Ключевые слова: инсулинорезистентность; зубочелюстная система; метаболические процессы; морфология.

\section{REFERENCES}

1. Maslianko VA, Pashkovska NV, Pavlovych LB, Olenovych OA, Iliushyna AA, Moroziuk YaV. Insulin resistance as a possible factor in the development of gestational diabetes mellitus in women with excess body weight. Int End J 2013;6(54). [Ukrainian].

2. Shamima Akter, Masafumi Eguchi, Takeshi Kochi, Isamu Kabe, Akiko Nanri, Tetsuya Mizoue. Association of serum calcium and phosphate concentrations with glucose metabolism markers: The furukawa nutrition and health study. Nutrients. 5;12(8):2344.

3. Raisingani M, Preneet B, Kohn B, Yakar S. Skeletal growth and bone mineral acquisition in type 1 diabetic children; abnormalities of the GH/IGF-1 axis. Growth Horm IGF Res. 2017;34:13-21.

4. Kannikar Wongdee, Nateetip Krishnamra, Narattaphol Charoenphandhu. Derangement of calcium metabolism in diabetes mellitus: negative outcome from the synergy between impaired bone turnover and intestinal calcium absorption. J Physiol Sci. 2017;67:71-81.

5. Kimak HB, Melnychuk HM. The influence of complex treatment on the indicators of carbohydrate exchange in young aged patients with generalized periodontitis. Clin Exp Pathol. 2018;17(1:63):56-60. [Ukrainian].

6. Antonyshyn IV, Marushchak MI, Brzhyskyi AV. Histological changes of white rats dental hard tissues during alimentary obesity. Word Med Biol. 2015;2(49):70-3. [Ukrainian].

7. Bila AY, Krasnoselskyy MV, Gramatyuk SM. The state of bioenergy metabolism and antioxidant enzymes in patients with breast cancer. Bull Probl Biol Med. 2015;4(2):77-80. [Ukrainian].

8. Onopchenko OV, Kosiakova GV, Goridko TM, Klimashevsky VM, Hula NM. The effect of N-stearoylethanolamine on liver phospholipid composition of rats with insulin resistance caused by alimentary obesity. Ukr Biochem J. 2014;86(1):101-10.

9. Shuprovych AA. Violation of uric acid metabolism in rats with experimental insulin resistant syndrome induced by fructose. Fiziol Zh. 2011;57(1):72-81. [Ukrainian].

10. Guranuch TV, Bagrii MM, Voronych-Semchenko NM. Structural changes of myocardium and liver in rats with thyroid hypofunction against the background of combine iodine and copper deficit. Sci Bull Uzhhorod Univ. 2014;1(49):6-10. [Ukrainian].

11. Pankiv VI. State of mineral density of bone tissue of women in postmenopausal period with primary hypothyroidism. Clin Exp Pathol. 2016;15(1):104-10. [Ukrainian]. 
12. Matolych UD. Variations of the healing of bone wounds posttraumatic osteomyelitis of mandible. Med Hydrol Reabil. 2013;11(2):37-9. [Ukrainian].

13. Bagrii MM, Dibrova VA. Methods of morphological examinations. Vinnytsia: Nova knyha. 2016:328. [Ukrainian].

14. Dvorshchenko K. Enzymatic activity of succinate dehydrogenase in mitochondria of mucosal cells of the stomach and hepatocytes of rats under conditions of an experimental ulcer. Biology. 2008;52-53:30-1. [Ukrainian].

15. Zamorskii II, Bukataru YS, Lenga EL, Kolisnyk SV, Altukhov OO. Screening of derivatives of 2-(benzoyilamino) (1-r-2-oxoindolin-3-ylidene) acetic acid under the conditions of acute hypobaric hypoxia. Sci J "ScienceRise: Pharmaceut Sci”. 2017;2(6):9-13. [Ukrainian].

Received 19.07.2021 